\title{
Universiteit
}

Leiden

The Netherlands

\section{Music in the Syrian city of Ebla in the late third millennium B.C.*}

Krispijn, T.J.H.; Dumbrill R.

\section{Citation}

Krispijn, T. J. H. (2010). Music in the Syrian city of Ebla in the late third millennium B.C.*. Proceedings Of The International Conference Of Near Eastern Archaeomusicology Iconea 2009 2010, 55-61. Retrieved from https://hdl.handle.net/1887/19251

Version: $\quad$ Not Applicable (or Unknown)

License: $\quad$ Leiden University Non-exclusive license

Downloaded from: $\quad$ https://hdl.handle.net/1887/19251

Note: To cite this publication please use the final published version (if applicable). 


\section{Edited by Richard Dumbrill}

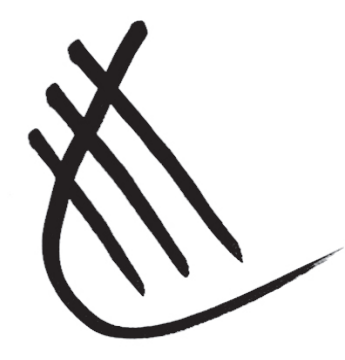

Prima la musica e poi le parole

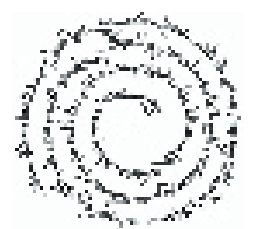




\section{Proceedings of the International Conference of}

Near Eastern Archaeomusicology

$$
\text { ICONEA } 2009 \text { - } 2010
$$

Held at the Université de la Sorbonne, November 2009 and at

Senate House, School of Musical Research

University of London, December 2010

A Publication of ICONEA

The International Conference of Near Eastern

Archaeomusicology

Institute of Musical Research

School of Advanced Study

University of London

Co-Published by 


\section{Foreword}

ICONEA 2009 was held at la Maison de la Recherche of the Université de la Sorbonne. The theme was Sumerian and Akkadian comparative philology/organology. Most of the debates were centralised on Theo Krispijn's work which had been published earlier in the proceedings of ICONEA 2008. During these three days of research, Krispijn presented the evidence for percussion instruments and I presented evidence for chordophones. Finkel proposed alternative understanding of early pictographs: what did they really represent and from which perspective should they be viewed. We arrived at the conclusion that in the absence of sufficient material, it is very difficult to isolate, indubitably, most instruments for a period of about three millennia.

For that reason, the editorial board of ICONEA decided not to publish the proceedings for that conference until further developments arise.

ICONEA is now a research group of the Institute of Musical Research, School of Advanced Study of the University of London. The 2010 conference was held at the Chancellor's Hall, Senate House, University of London and attracted leading scholars specialists of the Hyksos - and around the Hyksos period. Over ten countries were represented and much was learnt, ranging from cheironomic instructions to dance, to conch trumpets used as communication devices, etc. The proceedings are published in the present volume.

During the past year, ICONEA produced three public seminars per term. These have proven to be very successful and will therefore be continued in the future. Bruno de Florence gave a series of talks on the epistemological framework of music, from Aristotle to Descartes and Lacan. This attracted a great diversity of scholars ranging from theoreticians to analysts. His seminars will continue throughout the academic year and will be published in due time as a separate issue of ICONEA.

I introduced archaeomusicology at the University of Uludağ, in Bursa, Turkey, last Spring and we are currently drawing agreements with the department of archaeology for future academic exchanges between our two institutions. This aims at the creation of a sub-department of archaeomusicology at Bursa. It was also agreed that both institutions will jointly organise a conference in October 2012 on Bronze and Iron Age archaeomusicology in Ancient Turkey. Margaux Bousquet and myself attended the Damascus conference ORIENTAL LANSCAPES in May, organised by Hannibal Saad and the ministry of Culture. This conference attracted leading scholars of ethno and archaeomusicology. It was held mainly at the Dar al-Assad Opera House of Damascus. Concerts were given by soloists and ensembles such as the Damascus Festival Chamber Players; The Group Maqam of Syria; Hassan Taha, Syria; Zaid Jabri, Syria; Chafi Badreddin, Syria; Diaa Sukkary, Syria; Kinan Azmeh, Syria; Maias Yamani, Syria; Nouri Iskandar, Syria; Ibrahim Kevo, Syria; Indrani Mukherjee, India; Bushra Bashalani, Lebanon; Taisir Khalaf, Syria; The Byzantine Choir of St Romanos the Melodist of Homs; the Koukouyo Choir of the Syriac Church; Apurba Mukherjee, India; Essam Rafea, Syria; Omar Sarmini, Syria; the Nawa Band; The Annunciation Band; Fikret Karakaya, Turkey; Kinan Idnawi, Syria; Muhammad Qadri Dalal, Syria; Mohammad Mo'tamedi, Iran; Nidaa Abu Mrad, Lebanon; Yulduz Turdieva, Uzbekistan. 
The Sham Dervish Ensemble, Syria; Fira Shahrstan. Among ethno - archaeomusicologists were Jean During, CNRS France; Jameel Wilaya, Syria; Archbishop Joseph Absi, Syria; Hussain al-Aadhamy, Iraq; Richard Dumbrill, UK; Margaux Bousquet, France; Samim al-Sharif, Syria; Fira Sawah, Syria; Frederic Lagrange, France; Fawaz Baker, Syria; Mahmoud Guettat, Tunisia. I made my way to Beirut and spent a week with my colleague and friend Amine Beyhom. This led to the creation of NEMO-Online, a new research pool on Near Eastern Music with a review both available as a hard copy and online. ARANE publications have now been incorporated to NEMO-Online.

We are delighted to announce that Philippe Brunet member of ICONEA and of the academic board of NEMO-Online was awarded a silver medal for the Prix Jules Janin at the Academie Française for his recent translation of Homer's Iliad. Xavier Fresquet was awarded a Doctorate with 'mention très honorable' at the Université de la Sorbonne, on mediaeval zithers. The Jury which I presided was composed of Professor Frédéric Billiet, Dean of the UFR Music and musicology of the Sorbonne University and Madame la Professeure Marie-Bernadette Dufourcet-Hakim, thesis supervisors; Professors Florence Gétreau (CNRS), Isabelle Marchesin (Bordeaux) and Richard Dumbrill (London).

Jessica Hale is studying at SOAS for a MMus., a prelude to her doctoral thesis in archaeomusicology which she will defend at the Sorbonne. Margaux Bousquet is concluding her doctoral thesis, also at the Sorbonne.

ICONEA 2011 which was about the Oud from its Sumerian origins to modern times was a great success.

Richard Dumbrill 


\section{Copyright 2010 Richard Dumbrill}

All rights reserved under International and Pan-American Copyright Conventions.

No part of this volume may be reproduced or transmitted in any form or by any means, electronic or mechanical, including photocopy, recording, or any information storage and retrieval system, without prior permission in writing from the publisher, ICONEA, The International Conference of Near Eastern Archaeomusicology,

Institute of Musical Research, University of London, and the copublisher, Gorgias Press LLC.

All inquiries should be addressed to ICONEA

Co-Published by Gorgias Press LLC

180 Centennial Avenue

Piscataway, NJ 08854

$U S A$

Internet: www.gorgiaspress.com

Email: helpdesk@gorgiaspress.com

ISBN 978-1-4632-0182-1

This volume is printed on acid-free paper that meets the American National Standard for Permanence of paper for Printed Library Materials.

Printed in the United States of America 


\section{ICONEA 2009-2010 \\ Table of Contents}

EGYPTIAN FRACTIONS AND

THE ANCIENT SCIENCE

OF HARMONICS

Leon Crickmore

HAND POSITION OF MUSICIANS

BEFORE AND AFTER

THE HYKSOS KINGS

Magdalena Kuhn

SUMMON THE GODS

AND THE PEOPLE

TO THE SOUND OF THE CONCH

Elynn Gorris and Wim Verhulst

SINGERS, MUSICIANS AND THEIR

MOBILITY IN UR III PERIOD

CUNEIFORM TEXTS

Regine Pruzsinszky

ON THE MANIPULATION OF THE

PLANETS BY THE LYRE PLAYER IN

A 'WINE SONG' BY KHAMIS BAR

QARDAHE

Siam Bhayro
PYTHAGORAS,

THE ORIGINS OF MUSICAL MODI

AND THE DACTYLS

p.1 Peter Strauven \& Jan M.F. Van Reeth p.63

EGYPTIAN CONNECTIONS:

NARMER INSCRIPTIONS AS

SUMERIAN MUSICOLOGY

Ernest McClain

p. 73

p.11

MUSIC THEORISM IN THE

ANCIENT WORLD

Richard Dumbrill

THE EPISTEMOLOGICAL

p.21 FRAMEWORK OF MUSICOLOGY

Bruno de Florence

DANCE IN IRON AGE

ISRAEL/PALESTINE 1200 - 600 B.C.

ARCHAEOLOGICAL SOURCES AND

GLYPTIC ART

Bathyia Schachter

RECONSTRUCTING THE VOICE OF KING DAVID'S HARPS

Max Stern

p.161

DRUMS IN THE LATE XVIII ${ }^{\text {th }}$

DYNASTIES OF EGYPT

Lise Manniche

MUSIC IN THE SYRIAN CITY

OF EBLA IN THE LATE THIRD

MILLENNIUM B.C.

Theo J.H. Krispijn 


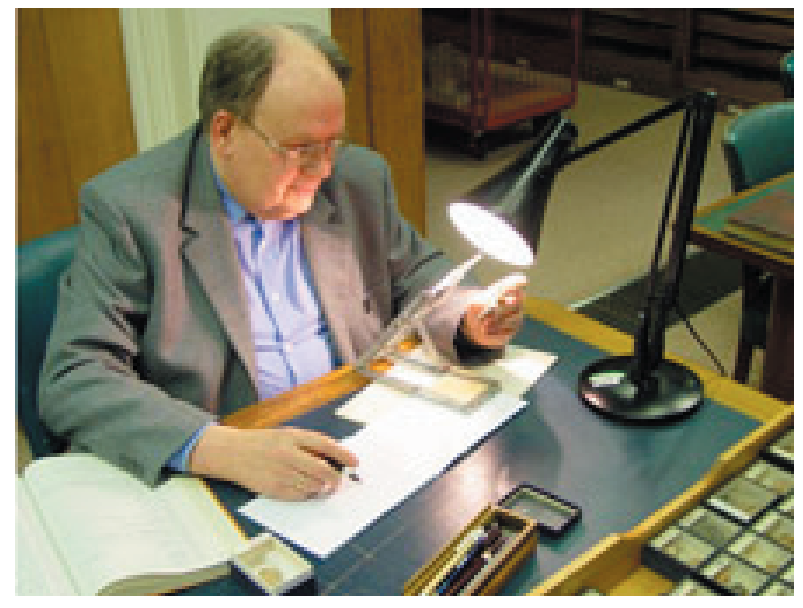

In memoriam, Rykle Borger 1929-2010

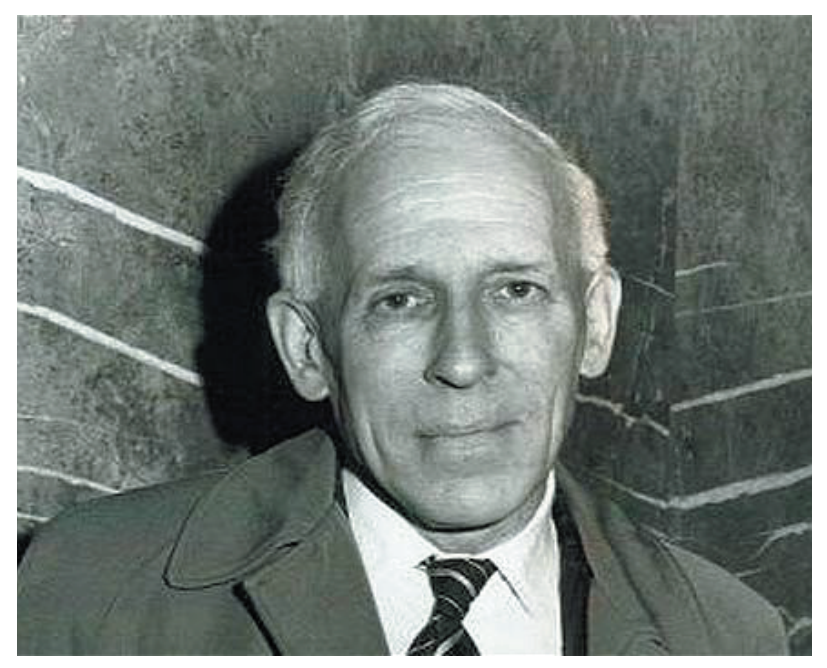

In memoriam, Wilfred Lambert 1926-2011 


\section{MUSIC IN THE SYRIAN CITY OF EBLA IN THE LATE THIRD MILLENNIUM B.C.*}

\section{Theo J.H. Krispijn}

\section{Landscapes:}

Syria forms the north-western part of the Fertile Crescent, a bridge between Egypt and Babylonia. Syria is especially interesting for archaeomusicologists, since a growing amount of material, textual as well as iconographic, has come from recent successful excavations. From the archives of Ebla and Mari we get a reasonably complete picture of musical instruments and musical practice in the late third millennium and the early second millennium. What we know from Ebla and Mari sources can help us to reconstruct the musical world of Syria, which formed the origin of many musical instruments imported into Egypt before and after the Hyksos kings.

When we look at the map of the Ancient Near East, it is obvious that Syria had to be divided into two regions: the Syro-Palestinian coast (the so-called Levant) and the Syrian hinterland dominated by the Orontes river, the Euphrates and its tributaries, the Balih and the Habur. The Euphrates provides the main route to Southern Mesopotamia, so that Syria is open to the East.

The situation in the West is somewhat different. Mountains not far from the coast form a natural border and make the coastal area,

* I am much indebted to Mervyn E. Richardson for improving the English of this paper and for some valuable suggestions concerning the paper itself. the northern Levant, different in character from the Syrian plains behind the mountains. The Levant has always been open to the West, receiving early visitors from Anatolia, Egypt, Cyprus and even from Greece. The most important centre in the northern part of the Levant was the city-state of Ugarit.

One of the most natural ways to enter the Syrian plain from the coast is through the Gate of Homs. Ancient Byblos, the city at the very beginning of the Gate of Homs, was guarding this 'gate'. That was the reason why Egypt used Byblos as a stronghold to maintain contact with the Syrian plain. Through the Gate one could reach important cities such as Qadesh, Qatna, Hama, Ebla, and Alalah.

\section{Music in Ebla ( \pm 2300 B.C.)}

Paolo Matthiae, director of the excavation team of the University of Rome at Tell Mardikh, started digging in the middle of the sixties of the $20^{\text {th }}$ century. Soon it became clear that he had found the ancient city of Ebla. Although Matthiae had reached the monumental royal palace on the Acropolis already in the early campaigns, it was a great surprise after ten years, in 1975, that the excavators found a large royal archive in a small room near the courtyard of Palace G. About 20000 tablets and fragments were found in this room, being the remains of administrative, scholarly, and literary archives stored on shelves. Only a small proportion appeared to be literary. The bulk concerned the administration of the royal palace. Most texts carefully recorded the administration of the annual royal gifts of clothes and silver to provincial rulers and local magistrates.

The texts were written in a local dialect of Akkadian, i.e. the Semitic language of Mesopotamia. This early form of Akkadian used many logograms borrowed from Sumerian, the language of Southern Mesopotamia, used in the scribal schools all over Mesopotamia and Syria. The scribes were apparently proficient bilingually, both in Akkadian and Sumerian. That must have been the reason that so many lexical texts, sign lists and vocabularies, have been found in Ebla. These vocabularies show strong links with the Mesopotamian lexical tradition, for the most part originating from Uruk in Southern Mesopotamia.

The palace of Ebla must have been built around 2300 B.C. and destroyed by Naram-Suen king 
of Akkade $\pm 2250 \mathrm{~B}$. C. The fire in the palace was apparently the reason why the wall collapsed and fell on to the archive room.

The Ebla texts contain many references to other cities, mostly nearby, but also as far as Kiš in Northern Babylonia. Most prominent were the contacts with Mari, Emar, and Nagar (Tell Brak), the bridge to the northern parts of Mesopotamia, which stood under the growing influence of Hurrian speaking populations. Some documents record conflicts between Ebla and Mari.
Musical instruments and musicians in Ebla iconography

A stele from Ebla dating from the early second millennium is one of few objects excavated in Ebla, which can certainly be linked with music. ${ }^{1}$ The other objects mentioned by Biga (La Musique à Ebla) are a bronze rattle and a relief decorated basin, which most likely depicts a cultic scene rather than a musical one. On the stele we can see a musical ensemble in the third register, with two drum players and another percussionist clapping
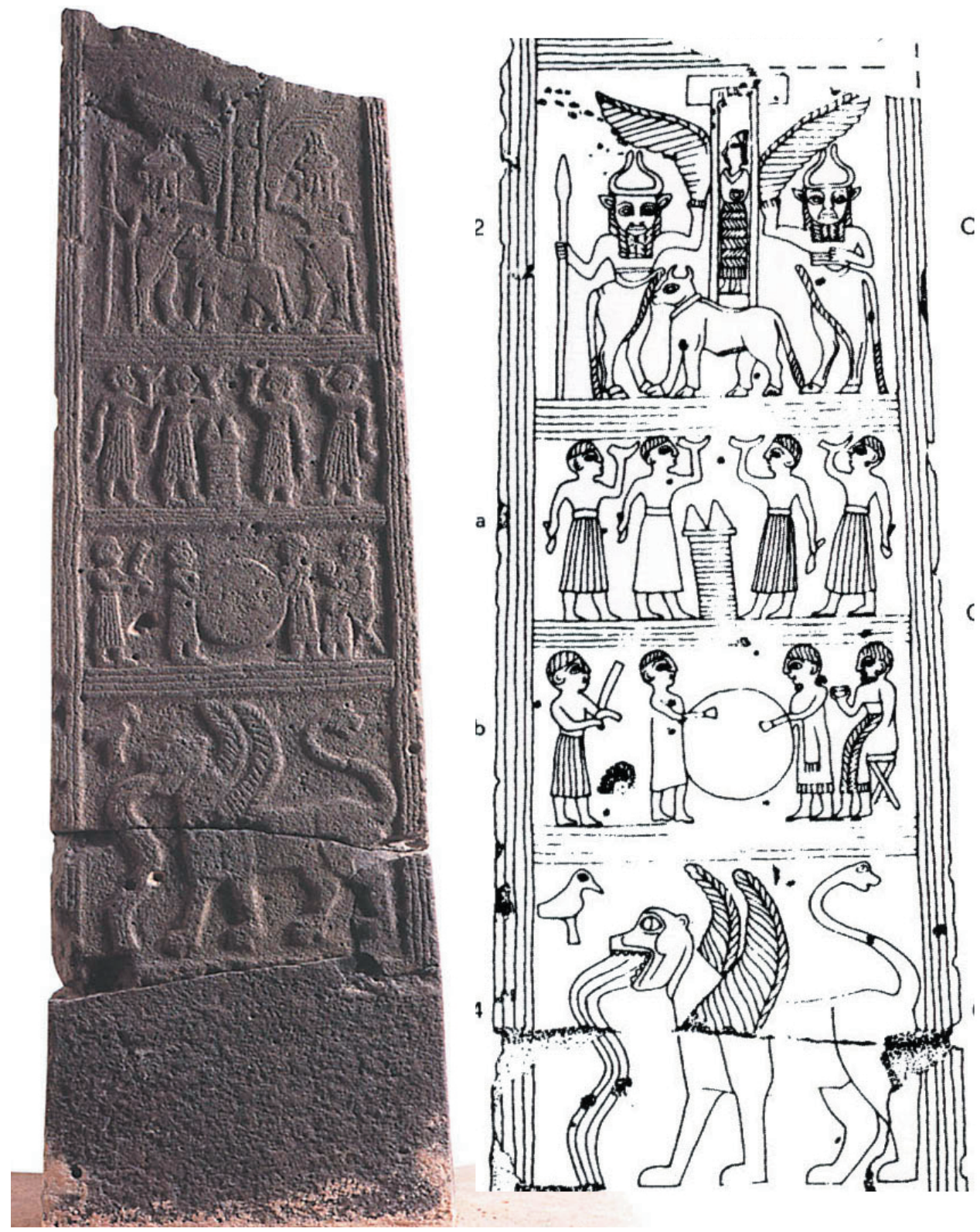
sticks, apparently accompanying a drinking scene with the ritual depicted above it. Comparable scenes are attested on the monuments from Southern Mesopotamia with a drum and clapping sticks. (Cf. Rashid, S.A., Musikgeschichte in Bildern Mesopotamian, Leipzig, 1984, Abb. 30.) The well-known animal orchestra consists of players clapping sticks in combination with a harp. In the later Syrian iconographic tradition we also find a cultic scene accompanied by a big drum, although one that is clearly smaller than those in Southern Mesopotamia. $^{2}$

\section{Textual sources on musical practice}

The administrative texts are the main evidence for music at Ebla. We meet several terms for musicians in these texts which associate them with certain instruments. ${ }^{3}$ The general terms are nar 'musician, singer' with its female equivalent nar. munus 'female musician, singer' and nar.mah 'chief musician'. Stringed instruments are played by the BALAĜ.DI (dubdu) 'harp player, tenor, wailer', which is used as a logogram for nātilum. The munabbitum 'female wailer' (Tonietti, Musicians, p. 84) sings with the female eme.bal 'choir singer' (Mari: muštawûm ?), with lú.balaĝ 'the man of the (stringed) instrument or the Syrian lyre', and with NAR.BALA $\hat{G}$ = tigi 'big lyre (player)'. Players of wind instruments include lú.gi.di 'the oboe player' and si 'the horn (player)'. Dancing or acrobatics were performed by the hub ${ }_{2}$ 'the dancer with clapping sticks' and the ne.di 'dancer'.

Local lexical tradition on musical instruments and musicians in Ebla

The Ebla scribes developed a long bilingual vocabulary, known as eš ${ }_{2}$.bar.UNKEN 'oracle' (later Sumerian eš.bar.kiĝ), according to the incipit, but more generally as 'Vocabulary of Ebla' ('Vocabulario di Ebla' VE) by Pettinato in MEE 4 (Pettinato, G., Testi lessicali bilingui della biblioteca L. 2769, (MEE 4), (Napoli, 1982). These vocabularies were developed on the basis of the 'Early Dynastic Practical Vocabularies' (EDPV) such as EDPVA. ${ }^{4}$ Several bilingual practical vocabularies existed beside the 'Vocabulary of Ebla'. Such practical vocabularies were described as 'Abstracts of the vocabulary' ('Estratti di Vocabulari' EV) by the original editor Pettinato (MEE 4). These lexical lists, which supply Sumerian words with an EblaAkkadian translation, contain the following terms for musicians and musical instruments. balaĝ: There are three equations of balaĝ: $=$ gi-na-lum rúm/ru $\mathrm{ru}_{12}$ um *kinnārum 'Syrian lyre' VE 572; = * balaggum (?) 'stringed instument (in general), type of song' VE 1242; ⿳⺈⿵⺆一 balag $=z u-m u-b a-r u_{12} *_{\text {zumbārum }}$ 'Anatolian lyre'(?) VE 364. The first entry translates balag with kinnārum, which occurs in the peripheral Akkadian of Mari (Old Babylonian) and Ugarit (Middle-Babylonian). Ugaritic knr and Hebrew kinnōr 'lyre' are cognate. Since it is attested only in the peripheral Syrian Akkadian, it must refer to a typical Syrian instrument. That is why it is translated here as 'Syrian lyre'. The second entry gives no translation. That could mean that the Sumerian word is taken over as the loanword balaggum in Ebla-Akkadian as it is in Mesopotamian Akkadian from the Sargonic period onwards, with giv in gิiš BALA $\hat{G}$, apparently a distinguishing determinative sign, separating balag $\hat{g}=*$ kinnārum from ${ }^{\text {gìs }}$ bala $\hat{g}=$ *zumbārum. The word zumbarum does not occur in Akkadian. The consonant cluster $/ \mathrm{mb} /$ points to a loanword from a Non-Semitic language. I tentatively suggest that zumbarum is a dialectal variant of the original Hattic word zinar/zannarum 'Anatolian lyre'. ${ }^{5}$ M. Civil discusses the different types of bala $\hat{g}$ in his publication of The Early Dynastic Practical Vocabulari A (Civil, M., The Lexical Texts in the Schøyen Collection CUSAS Volume 12 (Bethesda, 2010), pp. 99-101)

BALAĜ.DI = na-ti-lu-um *nātịlum 'lifting (his voice)' i.e. tenor, wailer' VE 571 is discussed by Fronzaroli (Miscellanea 3, p. 160), who connects it with Hebrew nțl 'to lift'. It must be an equivalent of Akkadian șārihum 'wailer', which is the translation of BALAG.DI in Mesopotamia. There is no gala 'lamentation singer' attested in Ebla, so BALA $\hat{G}$. $\mathrm{DI}=$ nătilum could have been the local term for it. BALAĜ.DI // națālum 'to lament' occurs also as a verb in a ritual context in ARET XI No 2 (66) // 1 (63) (Tonietti, Musicians, p. 85). eme.bal $=a-b i_{2}-$ lu-um, a-ba-(lu)-um, da-da-bi ${ }_{2}-l u$ *āpilum, *apālum, *tătappilum 'answering, to answer, to answer continuously' = 'to sing the antiphone' VE 179 is mentioned together with the munabbitum in ritual texts and (Tonietti, Musicians, p. 84 and Archi, A., 'Jewels for the ladies of Ebla', ZA 92 (2002), pp. 184-186). 
gi.di has two translations: ra-ḩa-lu gi *ahālu qanîm, 'to play (?) a reed (instrument)' i.e. 'oboe' VE $1390^{6}$ and $\mathrm{ba}^{-1 i_{2}}$-um *pari'um 'split reed' EV d 36; g 7. Civil (Practical Vocabulary A, p. 100) connects rahālum with Arabic a/urghūl 'double pipe'. In light of this equation it is attractive to combine it with ugula.nar $=\mathrm{ir}_{3}-\mathrm{e}_{2} / \mathrm{ir}_{3}-\mathrm{e}_{2}-[\mathrm{um}]$ *irhalum, pronounced / irhayum/, 'leader of the singers' VE 957, although it has pharyngal $h$ in stead of velar h. The other equation *pari'um 'cut through (reed)' might describe the shape of the 'double oboe. $\mathrm{gu}_{3}$. gi.di $=$ gi-dé *gidi(um) 'sound of the oboe' VE 218, a loanword from Sumerian, belongs also here. P. Fronzaroli (Miscellanea Eblaitica 1 (Firenze, 1988), pp. 46-47) has convincingly demonstrated that $A_{4-6}$ II 32" K[A ....] = na-ba-bu ${ }_{3}$-um *nabābum 'to pipe', from which embūbum 'oboe' is derived, belongs to this entry and not to the preceding one.

gi.tak $_{4}=$ zi-gal-[x]-mu ${ }^{*}$ sikallum (?) a type of flute VE 1230.

giv̌s.tag $=\mathrm{NI}-b u_{3}$-um *uppum 'drum' VE 366 beside $\hat{\mathrm{GIŠx}} \mathrm{TAK}_{4}=a-s a-r u_{12}-r u_{12}-(\mathrm{um})$ *asarrum 'wooden cylindrical drum' VE 437 (cf. Krispijn, ICONEA 2008, p. 150 note 31). hub $_{2}=-$ *huppûm 'dancer with clapping sticks' VE 876. hub ${ }_{2}$ has no translation in VE 876. That could mean that it is a loanword from Sumerian. ${ }^{7}$ nar $=$ - *nuārum 'singer, musician' In VE 875 nar has no translation, but a translation with the loanword nuārum is very likely. Since OldAssyrian has the non-contracted form nuārum, that does not seem to be a Sumerian word, a loanword from Akkadian into Sumerian is possible. ne.di $=$ ma-e $e_{2} / i_{3}$-lu-um *mahâlum or *mahlālum (?)'dancer' VE 845 is an abbreviation of e.ne.di 'to play, to dance'. maḥālum or *maḥlālum can be connected with Akkadian mèlulum 'to play, to dance' and Hebrew māḥōl 'line dancing' (Fronzaroli, P., Miscellanea Eblaitica 3, Quaderni di Semitistica 17 (Firenze, 1990), 201-203). ru.ru = mar-ba-a ${ }^{*}$ marba $^{c}(u m)$ 'two clappingsticks (forming a square ?)' VE 414. marbac um can be connected with Akkadian rubbûm 'to quadruple'. The clapping-sticks sometimes form a square, when clapped together (Rashid, S.A., Musikgeschichte in Bildern Band II, Lief. 2: Mesopotamien (Leipzig, 1984), p. $49 \mathrm{~N}^{\circ} 15$ and Durand, J.M., 'Des saltimbanques', in Ziegler, N. (ed.), La musique au Proche Orient ancien Dossier Archéologie et sciences des origines no. 370 (2006), p. 47).

si $=$ - *qarnum 'horn' (VE 1122) can be used as a musical instrument.

$\mathrm{za}_{3}$. $\mathrm{me}=$ wa-ti-um ${ }^{*}$ wadium 'praised, song of praise' (VE 1181) is originally a type of lyre, Akkadian sammû.

It is obvious that so many words for musical instruments and musicians were incorporated into these local lexical lists; only NAR.BALA $\hat{G}=$ tigi 'big lyre' is missing. Musicians include singers (nar 'singer', munabbitum 'female wailer', BALAĜ. $\mathrm{DI}=$ nātịlum 'tenor, wailer', eme.bal= āpilum 'choir member, antiphone singer'), string players

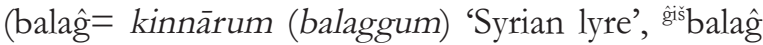
= zumbārum 'Anatolian lyre', NAR.BALAG $=$ tigi 'big lyre'), wind players (gi.di 'double oboe', si 'horn'), and dancers (ne.di = maḥālum or maḥlālum 'dancer', hubb ${ }_{2}$ 'dancer with clapping-sticks').

The Early dynastic lexical tradition concerning music in Ebla

The Mesopotamian lexical tradition started in about 3200 B.C. in Uruk in level IVa of the Eanna temple complex (Uruk IVa), but many lexical series were standardized only in about 3000 B.C. (Uruk III). In the Early dynastic period this lexical tradition was handed down and expanded by new series. Especially in Fara, ancient Šuruppak, and Abu Șālābīkh, a large collection of lexical materials was found. Ebla took over many Early Dynastic lexical series. These contain several terms for musicians and musical instruments, some of which we also find in the local developed lexical series, but others are restricted to the Mesopotamian tradition.

When we discuss the musical terms of the Mesopotamian lexical series found in Ebla, which do not occur in the locally developed series or in administrative and ritual texts, we must assume that the scribes knew these terms as words from the lexicon only and that the instruments named were not actually known to them.

One of the oldest lexical series, already found around 3200 B.C. (Uruk IVa), is a list of professions is Early Dynastic $l_{2}$ A (EDLuA). Many entries of this series, those for musicians included, start with the logogram GAL meaning 'big, great' in Sumerian. Since this GAL is missing in comparable entries 
from other series, a translation 'big one, leader' is not very likely. The sign $l_{2}$ 'man' is absent in this series, but frequent in other, mainly later, series on professions. Since GAL was pronounced /gal/ 'big' according to glosses to the Old-Babylonian version of $\mathrm{EDLuA}^{8}$, I tentatively suggest that GAL means 'adult' (indicating maturity) and not 'big' (indicating rank) and functions as the equivalent of the $\mathrm{lu}_{2}$ of the other lexical texts.

EDLuA 105-108 (Ebla version 77-80) contain the following musicians: gal.nar '(adult) musician, singer' (105). nar is found in all genres of texts in Ebla. gal.balag ' '(adult) harp player, wailer' (106) may be an abbreviation of balag.di 'wailer', well attested in Ebla.

gal.šùd '(adult) prayer singer' (107) and gal.zag '(adult) lyre player, singer of hymns' (108). zag/za can be an abbreviation of $\mathrm{za}_{3} \cdot \mathrm{me} / \mathrm{mi}_{2}$ 'lyre, song of praise, hymn', which only occurs with the meaning 'praise' in Ebla.

The Early dynastic List of Professions 'Early Dynastic Lú B' (EDlúE) is known from from Ebla sources (Pettinato, G., Testi lessicali monolingui della biblioteca L. 2769, (MEE 3) (Napoli, 1981, pp. 27-46). It contains 16 lines (98-113) with musical terms. Several lines known from sources outside Ebla are unfortunately broken in the Ebla version. These lines run partly parallel with lines of another early dynastic lexical series Wordlist B (206-215) . The musical entries of both series are tabulated below.

\section{Comparing the musical instruments of Mari}

Tell Hariri, ancient Mari, near the river Euphrates was a flourishing city during the late Early Dynastic and the Old-Babylonian period. The French excavators found large buildings from these periods, containing many objects of art and luxury, some of them imported from $\mathrm{Ur}$ in Southern Mesopotamia, Margueron, J.-C., Mari Métropole de l'Euphrate au III e et au début du II millénaire av. J.-C. (Paris, 2004), pp. 297-299). The name of the singer Ur-Nanše is perfect Sumerian and must stem from the city-state of Lagaš in Southern Mesopotamia. His name contains the element Nanše, a goddess which is mainly worshipped in Lagaš. He has had a harp in his hand. There are remains of a second statue of him on which parts of a harp are more clearly visible. This is another proof of the strong ties between Mari and Southern Mesopotamia.

Nele Ziegler has recently published a comprehensive study on the musical culture of Mari (Ziegler, N., Les musiciens et la musique d'après les archives de Mari, (Paris, 2007). I have listed the instruments, that she found in the archives in the table below. In the last column I have indicated whether these instruments are found in the Ebla texts.

It is obvious that the list of musical instruments named at Ebla from around 2350 B.C. differs greatly from those named at Mari 550 years later. The EDPV-A and EDLuE take an intermediate position with its connection with Middle (balag ma.ri ${ }_{2}=$ miritum) and Southern Mesopotamia (balaĝ. dilmun). Apparently several imported instruments had made their way to Mari from Iran: parahšitum and šebitum/sabitum. The terms for percussion instruments look different, but we are often not sure which Akkadian word could have been hidden behind an Early Dynastic logogram.

Ebla in the north-western corner of Syria must have been representative of the musical culture of Western Syria at the end of the third millennium B.C. Such a musical culture must have provided one of the sources of the instruments the Egyptians took over just before and during the Hyksos period. 
Table 1. Early Dynastic Lú B (EDLuE) 98-113 // Early Dynastic Practical Vocabulary A (EDPVA) ${ }^{1}$ 206-215.

\begin{tabular}{|c|c|c|c|c|}
\hline al.hub $_{2}$.balầ & a musical instrument (?) & & EDPV-A 205 & - \\
\hline balaĝ & stringed instrument & & EDPV-A 206 & VE $364,572,1242$ \\
\hline balaĝ.di & player of the harp, wailer & EDLuE 98 & & VE 571 \\
\hline balaĝ.dilmun & $\begin{array}{l}\text { (stringed) instrument of } \\
\text { Dilmun }\end{array}$ & & EDPV-A 207 & - \\
\hline balaĝ.ma.ri ${ }_{2}^{\mathrm{ki}}$ & $\begin{array}{l}\text { (stringed) instrument of } \\
\text { Mari }\end{array}$ & & EDPV-A 208 & - \\
\hline [za.am] & $\begin{array}{l}\text { player of the zamzam } \\
\text { percussion instrument }\end{array}$ & EDLuE 99 & & - \\
\hline$[\mathrm{x} . \mathrm{x}]$ & player of the? & EDLuE 100 & & $?$ \\
\hline [lú.a $\left.a_{2} \cdot \mathrm{la}_{2}\right]$ & player of the big drum & EDLuE 101 & & -10 \\
\hline [lú.gi.di] & $\begin{array}{l}\text { (player of the) double } \\
\text { oboe }\end{array}$ & EDLuE 102 & EDPV-A 209 & VE 1390 \\
\hline [lú.gi.TAG] & flute & & EDPV-A 210 & VE 1230 \\
\hline $\begin{array}{l}\text { [lú.GIxTAK }{ }_{4}= \\
\text { ub }_{\mathrm{x}} \text { ] }\end{array}$ & player of the flute & EDLuE 103 & & VE 1230 \\
\hline [lú.búr.BALAĜ]] & $\begin{array}{l}\text { (player of the) a type of } \\
\text { harp (?) }\end{array}$ & EDLuE 104 & EDPV-A 211 & - \\
\hline 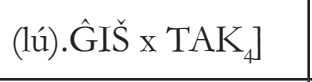 & $\begin{array}{l}\text { (player of the) wooden } \\
\text { drum }\end{array}$ & EDLuE 105 & EDPV-A 212 & VE 366 \\
\hline [LAK 387!'TAK 4 & (player of the) drum & EDLuE 106 & EDPV-A 213 & - \\
\hline lú.šir $_{3}$ & performer of songs & EDLuE 107 & & - \\
\hline lú.ad & humming (?) singer & EDLuE 108 & & - \\
\hline lú.SUM.tu & ... singer & EDLuE 109 & & - \\
\hline $\operatorname{šdd}_{3}(=\mathrm{SAGxŠU})$ & prayer singer (?) & EDLuE 110 & & - \\
\hline$\left[\operatorname{ama.šud}_{3}\right]$ & female prayer singer (?) & EDLuE 111 & & - \\
\hline [nu.ašs. di] & singer of curses (?) & EDLuE 112 & & - \\
\hline $\begin{array}{l}\text { [lú.šsu.du }{ }_{8} \cdot \mathrm{TAK}_{4} \cdot \\
\text { LAK 387] }\end{array}$ & man holding a drum & EDLuE 113 & & - \\
\hline ru.ru ${ }^{\text {uruda }}$ & metal clapping sticks & & EDPV-A 214 & VE 414 \\
\hline si.am.si & elephant's tusk & & EDPV-A 215 & (VE 1122) \\
\hline
\end{tabular}

Notes to the table:

- It is uncertain whether EDPV-A line 205 al.hub $_{2}$.balag belongs to the section of musical instruments, since most sections start with the most general term, in this case balag (206).

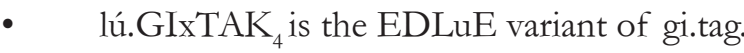

- $\quad$ Since šud ${ }_{3}$ ama.šud $_{3}$, nu.aš ${ }_{2}$.di $\left(<\operatorname{lu}_{2} \cdot \check{s}_{2}\right.$.di? $)$ are placed among terms for musicians, I assume that their activity was also musical. The gesture of praying and singing are largely comparable (Krispijn, forthcoming).

- The stringed instruments of Dilmun and Mari and the bur 2 .balag, some percussion instruments: za.am, $\mathrm{a}_{2} \cdot \mathrm{la}_{2}, \mathrm{ub}_{\mathrm{x}}\left(\mathrm{TAK}_{4} . \mathrm{LAK} 387\right)$ and the singer section (EDLuE 107-112) are missing in VE. 
Table 2. The musical instruments of the Mari-archives compared with those of Ebla

\begin{tabular}{|c|c|c|}
\hline algarsurrûm & horizontal harp with plectrum & - \\
\hline alûm & big drum & only in EDLuE 101 \\
\hline halhallatum & drum & 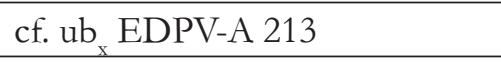 \\
\hline kinnārum & (Syrian) lyre & VE 572 \\
\hline lèum & 'board' a percussion instrument & - \\
\hline lilissu & kettle drum & - \\
\hline mirītum & lyre from Mari & only in EDPV-A 208 \\
\hline murumšûm (< mur(um) ša $\left.{ }_{4}\right)$ & $\begin{array}{l}\text { 'instrument that produces } \\
\text { a droning sound' precious } \\
\text { instrument decorated with ivory } \\
\text { and gold = giant lyre (?) }\end{array}$ & - \\
\hline parahšitum & instrument from Parahšum Iran & - \\
\hline pitnum & $\begin{array}{l}\text { general word for stringed } \\
\text { instrument }\end{array}$ & - \\
\hline sammû & lyre & - \\
\hline šebìtum/sabìtum & instrument of Sabûm & - \\
\hline tigitallum & a type of lute (?) & \\
\hline tigûm/tigitum & lyre player (male/female) & $\begin{array}{l}\text { only in administrative and ritual } \\
\text { texts. }\end{array}$ \\
\hline urzababìtum & type of lyre & - \\
\hline
\end{tabular}

\section{Notes}

1 See Biga, M.J., 'La musique à Ebla', in Ziegler, N. (ed.), La musique au Proche-Orient ancien Dossier Archéologie et. sciences des origines no 310 février 2006, pp. 24-31.

2 Cf. The relief from Karkemiš (Woolley, Carchemish II, (London, 1921), pl. B, 18b).

3 See Tonietti, M.V., 'Musicians in the Ebla Texts: A ThirdMillennium Local Source for Northern Syria', in Pruzsinszky, R. - Shehata, D. (ed.), Musiker und Tradierung Studien zur Rolle von Musikers bei der Verschriftlichung und Tradierung von Literarischen Werken Wiener Offene Orientalistik Band 8 (Wien, 2010), pp. 67-93. For the identification of instruments see Krispijn, T.J.H., ICONEA 2008 (London, 2010), 125-150.

4 M. Civil, The Early Dynastic Practical Vocabulary A (Archaic HAR-ra A) ARES IV, (Rome, 2008), p. 5.

5 Cf. Akkadian timbūtum < Sumerian budbu Krispijn, T.J.H., 'Beiträge zur altorientalischen Musikforschung 1 Šulgi und Musik', Akkadica 70 (1990), p. 23 footnote 40.

6 The combination with ša $a_{3} \cdot$ dar $=1 a-N I-l u-u m / \mathrm{ra}-\mathrm{NI}$-lum raHilum meaning 'split (of the heart), to be anxious' (?) VE 580 is not plausible (cf. Fronzaroli, Miscellanea 3, p. 163).

7 It is uncertain whether hub $b_{2} \cdot h u b_{2}=g u_{2}-d u-g u_{2}-d u-w u-$ um *qudqudûm 'jumping' EV v 40 is also a professional name. The reduplicated hub $_{2}$. hub ${ }_{2}$ looks to be a loan from Sumerian $\mathrm{gu}_{4} \cdot \mathrm{ud}_{\mathrm{gu}} \cdot \mathrm{ud}$ 'to jump constantly'. Cf. gu $\mathrm{gu}_{4} \cdot \mathrm{ud}_{\mathrm{gu}} \cdot \mathrm{ud}=$ ši-tahhu-t tu] 'to jump constantly' Izi G 250.
8 Cf. Green, M., Early Sumerian Tax Collectors, JCS 36 (1984), 93-95, and Civil, M., The Lexical Texts in the Schøyen Collection CUSAS Volume 12 (Bethesda, 2010), 193.

9 Complete edition now.

10 This series was designated 'Word list B' in the first publication of this series by Pettinato (G. Pettinato, Testi lessicali monolingui della biblioteca L. 2769, (MEE 3), (Neapoli,1981, pp. 143-155). Later M. Civil used respectively the designations 'Archaic HAR-ra A' and Early Dynastic Practical Vocabulary A (Civil, CUSAS 12, p. 203 footnote 39).

$11 \mathrm{a}_{2} \cdot \mathrm{l}_{2}=$ a-ba-lu-um *hablum (?)"rope" VE 573 is another lexeme.

12 M. Civil has discussed lines 205-215 in his commentary on EDPV-A (Civil, ARES IV, pp. 99-102). I have incorporated much of this discussion in my ICONEA 2008 article on pp. 144-148. 